\title{
Organization Relationship
}

National Cancer Institute

\section{Source}

National Cancer Institute. Organization Relationship. NCI Thesaurus. Code C93464.

Specifies the link between one organization and another. 